\title{
ZASADA PROPORCJONALNOŚCI A PODATKOWE OGRANICZENIA SWOBÓD RYNKU WEWNĘTRZNEGO UNII EUROPEJSKIEJ
}

\author{
I. ZASADA PROPORCJONALNOŚCI \\ JAKO OGÓLNA ZASADA PRAWA UNIJNEGO
}

Zasada proporcjonalności jako zasada prawna oparta jest na założeniu, że organy państwa, wykonując przyznane im uprawnienia, nie powinny ustanawiać nadmiernych ograniczeń w korzystaniu przez jednostkę z podstawowych praw i wolności. Początki tak rozumianej zasady proporcjonalności sięgają końca XIX w., kiedy pojawiła się ona w orzecznictwie pruskim jako ochrona jednostek przed rosnącymi uprawnieniami administracji; współcześnie natomiast zasadę tę postrzegać należy jako jedną z konsekwencji koncepcji państwa liberalnego, która zakłada, że państwo powinno ograniczyć się do osiagania konkretnych celów, a prawo musi służyć „użytecznemu zamiarowi”.

Zasada proporcjonalności należy do zasad ogólnych prawa unijnego wypracowanych przez Europejski Trybunał Sprawiedliwości (obecnie Trybunał Sprawiedliwości UE). Ogólne zasady prawa - gdy pozwala na to ich treść - zaliczane są do pierwotnego prawa Unii Europejskiej². Pojęcie ogólnych zasad prawa odnosi się przy tym do podstaw danego systemu prawnego i fundamentalnych wartości, na których ów system został zbudowany; mamy zatem do czynienia z normami o „wysokim stopniu ogólności i niedoprecyzowanym charakterze”.

Rolę zasad ogólnych prawa unijnego - zarówno tych unormowanych w przepisach traktatowych, jak i będących efektem działalności orzeczniczej Trybunału Sprawiedliwości UE (dalej: Trybunał, TSUE) - trafnie określa się jako uzupełniającą w stosunku do innych elementów unijnego systemu normatywnego i wskazuje, że zasady stają się elementem rekonstrukcji innych norm w samym procesie wykładni prawa, zmieniając w określonych przypadkach zakres normowania wynikajacy z wykorzystania reguł językowych interpretacji

${ }^{1}$ A. Frąckowiak-Adamska, Zasada proporcjonalności jako gwarancja swobód rynku wewnętrznego Wspólnoty Europejskiej, Warszawa 2009, s. 24.

${ }^{2}$ D. Sobczyński, Zasada proporcjonalności w europejskim prawie wspólnotowym, „Glosa” 2003, nr 7, s. 8.

${ }^{3}$ J. Maliszewska-Nienartowicz, Zasady ogólne prawa jako źródło europejskiego prawa wspólnotowego, „Państwo i Prawo” 60, 2005, z. 4, s. 23.

${ }^{4}$ A. Kalisz-Prakopik, L. Leszczyński, Zasady prawa w stosowaniu prawa wspólnotowego, „Europejski Przegląd Sądowy” 2005, nr 10, s. 24. 
Zasada proporcjonalności uregulowana została przepisami art. 5 Traktatu o Unii Europejskiej ${ }^{5}$. Zgodnie z art. 5 ust. 1 TUE granice kompetencji Unii wyznacza zasada przyznania. Zgodnie z zasadą proporcjonalności zakres i forma działania Unii nie wykraczają poza to, co jest konieczne do osiagnięcia celów Traktatów, a instytucje Unii stosują zasadę proporcjonalności zgodnie z Protokołem w sprawie stosowania zasad pomocniczości i proporcjonalności (art. 5 ust. 4. TUE).

Literalnie zatem traktatowa zasada proporcjonalności skierowana jest do instytucji unijnych, które powinny szacować, czy w ramach swojej działalności sięgają po środki adekwatne do założonych celów. Zasada proporcjonalności ma zatem charakter skodyfikowanej ogólnej zasady prawa unijnego, która jest wykorzystywana przez TSUE w celu badania, czy obciążenie nałożone na adresatów określonych norm unijnych jest ograniczone w stopniu niezbędnym do osiąnięcia założonego celu i spełnione być może przy możliwie najmniejszej dolegliwości dla jego adresatów ${ }^{6}$. W takim ujęciu zasada proporcjonalności, jako ogólna zasad prawa unijnego, wymaga, aby akty prawa unijnego nie wykraczały poza to, co odpowiednie i konieczne do realizacji uzasadnionych celów, którym mają służyć. Natomiast tam, gdzie istnieje możliwość wyboru spośród większej liczby odpowiednich rozwiązań, należy stosować te najmniej dotkliwe, a wynikające $\mathrm{z}$ tego niedogodności nie powinny być nadmierne w stosunku do zamierzonych celów ${ }^{7}$. Podkreśla się w tym kontekście dualizm zasady proporcjonalności, z jednej strony wiąże się ona $\mathrm{z}$ ochroną jednostek przed nadmiernymi środkami unijnymi, z drugiej zaś - z ochroną państw członkowskich przed nieuzasadnioną ingerencją UE w ich suwerenność ${ }^{8}$. Trybunał Sprawiedliwości wykorzystuje jednak zasadę proporcjonalności nie tylko do oceny adekwatności działań instytucji unijnych, ale rozszerzył zakres jej do badania, czy państwa członkowskie, które korzystaja z prawa do derogacji od szeregu norm unijnych, nie nadużywają tego prawa do osiagnięcia różnego rodzaju celów gospodarczych o charakterze protekcjonistycznym, ograniczając swobody rynku wewnętrznego.

Zasada proporcjonalności w takim rozumieniu ma zatem za zadanie ograniczać arbitralność państw UE w wykorzystywaniu posiadanych kompetencji i stanowić tym samym środek gwarantujaccy wykorzystywanie przyznanych im przez prawo unijne uprawnień do realizacji dopuszczalnych celów - w szczególności chronić przez nadużywaniem generalnych klauzul uzasadniajacych ograniczanie swobód rynku wewnętrznego ${ }^{9}$.

${ }^{5}$ Dz. Urz. UE z 30 marca 2010 r., 2010/C 83/01.

${ }_{6}$ D. Sobczyński, op. cit., s. 8-9.

7 Zob. wyrok TS z 11 czerwca 2009 r. w sprawie C-33/08 - Agrana Zucker GmbH v. Bundesministerium für Land- und Forstwirtschaft, Unwelt und Wasserwirtschaft, ECR [2009], s. I-5035, pkt 31.

${ }^{8}$ T. Ostropolski, Zasada proporcjonalności a europejski nakaz aresztowania, „Europejski Przegląd Sądowy" 2013, nr 3, s. 15.

9 A. Cieśliński, Wspólnotowe prawo gospodarcze, t. 1: Swobody rynku wewnętrznego, Warszawa 2009, s. 87. 


\section{ZAGADNIENIE PROPORCJONALNOŚCI KRAJOWYCH REGULACJI OGRANICZAJĄCYCH SWOBODY RYNKU WEWNĘTRZNEGO}

Jedna z podstawowych funkcji zasady proporcjonalności w kontekście Unii Europejskiej jest promowanie integracji gospodarczej państw członkowskich. Zakres zastosowania zasady proporcjonalności jest szeroki i służy do oceny przepisów państw członkowskich ograniczających możliwość korzystania ze swobód rynku wewnętrznego oraz przepisów skutkujących dyskryminacją towarów, przedsiębiorców lub pracowników z innych państw członkowskich ${ }^{10}$.

W tym kontekście ograniczenie swobód rynku wewnętrznego wymaga od państwa członkowskiego szczegółowego uzasadnienia, że zastosowany środek prawny (faktyczny) jest rzeczywiście niezbędny do osiagnięcia założonego celu (celów) oraz że niemożliwe jest zastosowanie mniej dolegliwych dla adresatów narzędzi ${ }^{11}$.

Krajowe środki (faktyczne lub prawne) mogą być uzasadnione tylko wtedy, gdy interes krajowy, który podlega ochronie, nie może być chroniony tak samo skutecznie przez środki mniej ograniczające wymianę wewnątrzwspólnotowa - proporcjonalność pozwala więc na eliminowanie środków niepotrzebnych lub nadmiernie ograniczających wolności wspólnotowe ${ }^{12}$, a w szczególności swobody rynku wewnętrznego.

W tym kontekście podkreśla się znaczenie zasady proporcjonalności jako istotnego instrumentu unijnej integracji gospodarczej; w odniesieniu do swobód rynku wewnętrznego proporcjonalność traktowana jest jako normatywny wyraz integracji negatywnej (wynikajacej z konieczności dostosowywania krajowych regulacji do prawa unijnego, nawet $\mathrm{w}$ obszarach formalnie pozostajacych w autonomii państw członkowskich) i zasadę wymuszająca jak najszerszy dostęp do rynków krajowych ${ }^{13}$, zarówno w ujęciu podmiotowym, jak i przedmiotowym.

Dla badania proporcjonalności w takim rozumieniu stosowane są tzw. testy proporcjonalności. Takis Tridimas wskazuje, że niezbędne jest przeprowadzenia dwóch testów: testu odpowiedniości oraz testu konieczności ${ }^{14}$. Pierwszy odnosi się do relacji pomiędzy zastosowanym środkiem a zamierzonym celem, drugi natomiast do ważenia znaczenia konkurujących ze sobą interesów. Z kolei rzecznik generalna Verica Trstenjak - na podstawie analizy orzecznictwa Trybunału - proponuje trójczłonowy schemat (test) sprawdzania proporcjonalności, zakładający ocenę badanej normy w kontekście: odpowiedniego charakteru, niezbędnego (koniecznego) charakteru oraz współmierności danego działania ${ }^{15}$.

${ }^{10}$ A. Wróbel (red.), Stosowanie prawa Unii Europejskiej przez sądy, Lex 46634.

11 A. Cieśliński, op. cit., s. 88.

12 Ibidem, s. 86.

13 T. Tridimas, The General Principles of EU Law, New York 2007, s. 193.

14 Ibidem, s. 139.

15 Zob. opinia rzecznika generalnego V. Trstenjak z 8 marca 2011 r. w sprawie C-10/10 - Komisja Europejska v. Republika Austrii, pkt 68. 
Z orzecznictwa Trybunału wynika, że określone działanie na rzecz osiagnięcia wytyczonego celu może być uznane za odpowiednie (właściwe), jeżeli faktycznie jest w stanie sprostać dążeniu do zrealizowania go w sposób spójny i systematyczny. Z kolei określone działanie jest niezbędne (konieczne), jeśli spośród wielu działań właściwych do osiagnięcia danego celu jest tym, które jest najmniej obciążające dla danego interesu lub danego dobra. O nieodpowiednim ograniczeniu swobody przepływu możemy zatem mówić w sytuacji, gdy krajowe środki - mimo swego wkładu w realizację celu leżącego w interesie ogółu - prowadziłyby do nieproporcjonalnie dużej ingerencji w swobodę przepływu $^{16}$.

Przywoływany jest ponadto tzw. test Gerharda, w świetle którego badany przepis powinien być właściwy do zagwarantowania uzyskania pożądanych celów oraz nie wykraczać poza to, co niezbędna do ich osiagnięcia. W odniesieniu do pierwszego z warunków wskazuje się na wymóg ogólnej oceny odpowiedniości badanej normy; w odniesieniu do drugiego z warunków niezbędna jest analiza, czy podlegający ochronie interes ogólny można zagwarantować, stosując normę mniej dolegliwą (restrykcyjna ${ }^{17}$.

Trybunał Sprawiedliwości uznaje przy tym, że ustawodawstwo krajowe jest właściwe do zapewnienia realizacji wskazanego celu, „tylko jeśli jego osiąnięcie jest rzeczywistym przedmiotem troski tego ustawodawstwa w sposób spójny i systematyczny"18. Zasada proporcjonalności ogranicza zatem arbitralność państw UE w wykonywaniu władzy i wymusza wyważony dobór środków krajowych używanych do osiagnięcia zakładanych celów ${ }^{19}$.

Podkreśla się, że badanie proporcjonalności krajowych środków legislacyjnych jest szczególnie istotne w sytuacji, gdy wykluczają one transgraniczne czynności prawne dokonywane na rynku wewnętrznym z zakresu zastosowania regulacji przewidzianych $\mathrm{w}$ prawie państwa członkowskiego ${ }^{20}$.

\section{ZASADA PROPORCJONALNOŚCI A OGRANICZENIA SWOBÓD RYNKU WEWNETRZNEGO W SFERZE PODATKÓW BEZPOŚREDNICH}

W odniesieniu do gwarantowanych traktatowo swobód rynku wewnętrznego (swoboda przepływu towarów, osób, kapitału i usług oraz swoboda przedsiębiorczości - określane również jako swobody fundamentalne bądź swobody

${ }^{16}$ Zob. m.in. wyroki TS: z 17 listopada 2009 r. w sprawie C-169/08 - Presidente del Consiglio dei Ministri v. Regione Sardegna, ECR [2009], s. I-10821, pkt 42; z 11 lipca 1989 r. w sprawie 265/87 - Hermann Schräder HS Kraftfutter GmbH \& Co. KG v. Hauptzollamt Gronau, ECR [1989], s. 2237, pkt 21.

${ }^{17}$ Ł. Adamczyk, Fundamentalne swobody prawa WE i ich znaczenie dla podatków bezpośrednich, w: H. Litwińczuk (red.), Podatki bezpośrednie. Prawo polskie a prawo wspólnotowe, Warszawa 2009 , s. 292.

${ }_{18}$ Zob. wyrok TS z 10 marca 2009 r. w sprawie C-169/07 - Hartlauer Handelsgesellschaft mbH v. Wiener Landesregierung, Oberösterreichische Landesregierung, ECR [2009] s. I-1721, pkt 55.

19 A. Cieśliński, op. cit., s. 89.

${ }^{20}$ R. Barents, Directory of EC Case Law on Direct Taxation, Alphen aan den Rijn 2009, s. 124. 
przepływu) zasadzie proporcjonalności przypisuje się szczególną funkcję - promocji integracji gospodarczej w Unii Europejskiej ${ }^{21}$. Zasada proporcjonalności może być zatem postrzegana jako instrument wykorzystywany przez Trybunał do „wymuszania” tzw. negatywnej integracji gospodarczej oraz zasada wzmacniajacca gwarancje nieskrępowanego dostępu do rynków państw członkowskich wyrażone swobodami rynku wewnętrznego.

W obszarze opodatkowania bezpośredniego państwa członkowskie zachowały znaczący zakres formalnej suwerenności. Jednakże orzecznictwo TSUE w wielu przypadkach skutkuje ingerencją w krajowe regulacje podatkowe, których negatywna ocena pod kątem zgodności ze swobodami rynku wewnętrznego obliguje państwa członkowskie do dostosowania regulacji krajowych do unijnego wzorca, niepochodzącego wszakże od unijnego prawodawcy.

Swobody przepływu (poza swobodą przepływu kapitału) nie odnoszą się do kwestii opodatkowania bezpośredniego, jednakże pomimo daleko posuniętej autonomii państw UE w kształtowaniu regulacji prawnych w tej sferze, Trybunał Sprawiedliwości UE konsekwentnie promuje linię orzecznicza, w świetle której owa autonomia nie jest nieograniczona i powinna być realizowana $\mathrm{z}$ poszanowaniem prawa unijnego, a w szczególności swobód rynku wewnętrznego ${ }^{22}$.

Zgodzić należy się z poglądem, że swobód rynku wewnętrznego nie można ograniczać do prostych gwarancji niedyskryminacyjnego traktowania ze względu na pochodzenie osób (towarów, kapitału) w UE - swobody wymusiły bowiem istotne ograniczanie kompetencji państw członkowskich oraz akceptację daleko idącej ingerencji w funkcjonowanie gospodarek narodowych ${ }^{23}$. Ponadto swobody przepływu uznaje się za istotny instrument ochrony prawnej jednostki w systemie unijnym. Pomimo swojego fundamentalnego charakteru swobody rynku wewnętrznego nie mają w większości przypadków charakteru bezwzględnego. Prawodawca unijny dopuszcza bowiem w przepisach Traktatu o funkcjonowaniu Unii Europejskiej (dalej: TfUE) ich ograniczanie przez państwa członkowskie, powodowane m.in. względami porządku publicznego, bezpieczeństwa publicznego, ochrony zdrowia i życia ludzi czy nawet moralności publicznej. Owe derogacje określa się mianem „wentyli bezpieczeństwa”, które pozwalają uzasadnić państwu członkowskiemu bezpośrednia dyskryminację, służąc tym samym ochronie wartości, które nie mają wymiaru czysto ekonomicznego ${ }^{24}$. Trybunał swoją praktyką orzeczniczą rozszerzył jednak zakres traktatowych derogacji przez stosowanie tzw. podatkowych względów interesu ogólnego, do których Trybunał zalicza m.in.: spójność systemów podatkowych państw członkowskich, zrównoważony podział kompetencji podatkowych między państwami UE, przeciwdziałanie unikaniu i uchylaniu się od

21 T. Tridimas, op. cit., s. 193.

${ }_{22}$ Zob. m.in. wyroki TS: z 14 lutego 1995 r. w sprawie C-279/93 - Finanzamt Köln-Altstadt v. Roland Schumacker, ECR [1995] s. I-225, pkt 21; z 11 sierpnia 1995 r. w sprawie C-80/94 G. H. E. J. Wielockx v. Inspecteur der Directe Belastingen, ECR [1995], s. I-02493, pkt 16.

23 A. Cieśliński, Konstrukcja prawna swobód rynku wewnętrznego Unii Europejskiej, Wrocław 2013, s. 53.

${ }^{24}$ A. Wróbel (red.), op. cit. 
opodatkowania, skuteczność kontroli podatkowych, czy zmniejszenie dochodów podatkowych do budżetów państw członkowskich.

Ze względu na fakt, że swobody rynku wewnętrznego normatywnie zostały oparte na zasadzie niedyskryminacji z uwagi na przynależność państwowa, nawet jeżeli krajowe regulacje ograniczające określoną swobodę znajdują uzasadnienie w traktatowych bądź pozatraktatowych względach - ograniczenia te muszą spełniać postulat proporcjonalności użytych środków w stosunku do założonych celów ${ }^{25}$.

Możliwość wykorzystania konstrukcji prawnej swobód przepływu w kontekście podatkowych względów interesu ogólnego do oceny szczegółowych norm zawartych w wewnętrznych systemach podatków bezpośrednich państw UE jest, nawet dla TSUE, zadaniem trudnym. Być może dlatego Trybunał coraz częściej dla rozstrzygnięcia, czy określona norma podatkowa stanowi naruszenie swobód, przeprowadza test proporcjonalności zastosowanych krajowych środków prawnych bądź faktycznych do założonych przez prawodawcę krajowego celów. Zasada proporcjonalności, stosowana w kontekście gwarancji swobód rynku wewnętrznego, oznacza zatem, że środek krajowy ograniczający swobody rynku wewnętrznego powinien być proporcjonalny, a wszystkie wyjątki od swobód rynku wewnętrznego powinny być interpretowane w świetle tej zasady ${ }^{26}$. Jak stwierdził Trybunał w wyroku w sprawie Schwarz, różnica $\mathrm{w}$ traktowaniu na gruncie prawa podatkowego w sytuacjach transgranicznych, które są obiektywnie porównywalne, może być uzasadniona jedynie wówczas, gdy jest oparta na obiektywnych przesłankach, proporcjonalnych do celu realizowanego przez prawo krajowe ${ }^{27}$.

$\mathrm{Z}$ drugiej strony swobody rynku wewnętrznego oraz zasada niedyskryminacji moga $z$ stanowić uzasadnienie ingerencji $\mathrm{w}$ kompetencje prawodawcze państw członkowskich w sferze podatków bezpośrednich, ale tylko w sytuacji gdy są używane do realizacji celów pozostających w zgodzie z zasadami krajowych systemów podatkowych państw członkowskich. Taki warunek może być spełniony tylko wtedy, gdy swobody przepływu interpretowane są w świetle zasady proporcjonalności. Zgodnie z ugruntowanym orzecznictwem Trybunału przepisy krajowe utrudniające lub zniechęcające do wykonywania traktatowych swobód rynku wewnętrznego moga zostać uznane za uzasadnione, jeżeli służą celowi leżącemu w interesie ogólnym, są właściwe do zapewnienia osiagnięcia tego celu oraz nie wykraczaja poza to, co jest konieczne do jego osiagnięcia ${ }^{28}$.

Analiza orzecznictwa Trybunału pozwala na wyodrębnienie dwóch głównych grup orzeczeń, w których zasada proporcjonalności jest wykorzystywa-

${ }_{25}$ V. E. Metzler, The Relevance of the Fundamental Freedoms for Direct Taxation, w: M. Lang et al. (eds.), Introduction to European Tax Law on Direct Taxation, Wien 2008, s. 64.

${ }^{26}$ A. Frąckowiak-Adamska, op. cit., s. 180.

27 Zob. wyrok TS z 11 września 2007 r. w sprawie C-76/05 - Herbert Schwarz, Marga Gootjes-Schwarz v. Finanzamt Bergisch Gladbach, ECR [2007], s. I-6849, pkt 94.

${ }_{28}$ Zob. m.in. wyroki TS: z 6 czerwca 2000 r. w sprawie C-35/98 - Staatssecretaris van Financiën v. B.G.M. Verkooijen, ERC [2000], s. I-4071, pkt 43; z 12 grudnia 2006 r. w sprawie C-374/04 - Test Claimants in Class IV of the ACT Group Litigation v. Commissioners of Inland Revenue, ECR [2006], s. I-11673, pkt 68. 
na do „ważenia” suwerenności podatkowej państw członkowskich w sferze podatków bezpośrednich oraz obowiązku zagwarantowania swobód rynku wewnętrznego. Do pierwszej grupy zaliczyć można orzeczenia, w których zasada proporcjonalności stosowana jest w kontekście regulacji o charakterze materialnym, do drugiej natomiast $-\mathrm{w}$ aspekcie proceduralnym.

Niewątpliwie fundamentalny wpływ na stosowania zasady proporcjonalności w kontekście oceny regulacji państw członkowskich w kwestii podatkowych ograniczeń swobód rynku wewnętrznego w obu aspektach (materialnym i proceduralnym) miało orzeczenie $\mathrm{w}$ sprawie Test Claimants. $\mathrm{Z}$ orzeczenia tego wynika, że za niewykraczająca poza to, co jest konieczne (proporcjonalne) do zapobieżenia oszustwom podatkowym i unikaniu opodatkowania (czyli jednemu ze względów interesu ogólnego), można uznać regulację krajowa, która oparta jest na ocenie elementów obiektywnych i możliwych do zweryfikowania w celu ustalenia, czy dana transakcja stanowi „całkowicie sztuczna konstrukcję" wyłącznie dla celów podatkowych, i która w każdym przypadku, gdy nie można wykluczyć istnienia takiej struktury, umożliwia podatnikowi - bez poddawania go nadmiernym utrudnieniom administracyjnym - przedstawienie dowodów dotyczących ewentualnych aspektów handlowych (biznesowych), które uzasadniały zawarcie danej transakcji29.

W tym kontekście warto przywołać rozstrzygnięcie Trybunału w wyroku w sprawie Glaxo Wellcome, w którym ocenie poddał możliwość powoływania się przez państwa UE dla ograniczenia swobody rynku wewnętrznego przepisami podatkowymi na nadrzędny cel, jakim jest zapobieganie czysto sztucznym strukturom gospodarczym tworzonym przez przedsiębiorców w oderwaniu od przyczyn ekonomicznych, a których jedynym zadaniem jest uzyskanie korzyści podatkowej. Trybunał stwierdził, że aby zasada proporcjonalności została zachowana, zastosowany przez państwo UE ,środek mający osiagnąć taki cel, powinien pozwolić sądowi krajowemu na odrębną analizę każdego przypadku, z uwzględnieniem jego szczególnych okoliczności i w oparciu o elementy obiektywne"so.

Z kolei w wyroku w sprawie $N$. Trybunał uznał ustanowienie gwarancji wymaganych od osób fizycznych przenoszących rezydencję podatkową do innego państwa członkowskiego i pragnących skorzystać z odroczonej zapłaty podatku od cichych rezerw związanych z papierami wartościowymi za nieproporcjonalne do realizowanych przez państwa członkowskie celów interesu ogólnego. Trybunał uznał, iż istniały mniej restrykcyjne z punktu widzenia swobód rynku wewnętrznego środki, takie jak wprowadzone na poziomie Unii Europejskiej mechanizmy wzajemnej pomocy, w szczególności w dziedzinie egzekucji wierzytelności podatkowych ${ }^{31}$.

\footnotetext{
${ }_{29}$ Zob. wyrok TS z 13 marca 2007 r. w sprawie C-524/04 - Test Claimants in the Thin Cap Group Litigation v. Commissioners of Inland Revenue, ECR [2007], s. I-2107, pkt 82.

${ }^{30}$ Zob. wyrok TS z 17 września 2009 r. w sprawie C-182/08 - Glaxo Wellcome GmbH \& Co. KG v. Finanzamt München II, ECR [2009], s. I-8591, pkt 99.

${ }^{31}$ Zob. wyrok TS z 7 września 2006 r. w sprawie C-470/04 - N v. Inspecteur van de Belastingdienst Oost/kantoor Almelo, ECR [2006], s. I-7409, pkt 51.
} 
W wyroku w sprawie National Grid Trybunał, oceniając opodatkowanie niezrealizowanych zysków związanych z majątkiem spółki przenoszącej siedzibę między państwami członkowskimi w świetle swobody przedsiębiorczości, uznał za nieproporcjonalne regulacje państwa członkowskiego, które przewidują natychmiastowy pobór podatku od niezrealizowanych zysków związanych ze składnikami majątkowymi spółki przenoszącej siedzibę faktycznego zarządu do innego państwa członkowskiego w chwili takiego przeniesienia. Sama okoliczność, że spółka przenosi siedzibę do innego państwa członkowskiego, nie może bowiem uzasadniać „ogólnego domniemania oszustwa podatkowego" i usprawiedliwiać środka naruszającego wykonywanie jednej ze swobód przepływu ${ }^{32}$.

Jak już wspomniano, Trybunał wykorzystuje również zasadę proporcjonalności do oceny przepisów proceduralnych państw członkowskich w kontekście poboru i kontroli podatków bezpośrednich.

Przykładowo w wyroku w sprawie E.H.A. Passenheim TSUE ocenił, iż dodatkowy termin przysługujący organom podatkowym danego państwa członkowskiego w celu dokonania określenia wysokości zobowiązania podatkowego dotyczącego elementów podstawy opodatkowania znajdujących się lub majacych swe źródło w innym państwie członkowskim nie zawsze odpowiada terminowi potrzebnemu tym organom do zweryfikowania określonych informacji w tym innym państwie członkowskim. Jednakże, zdaniem Trybunału, nie wynika z tego, iż przedłużenie okresu, w którym organy podatkowe mogą wydać decyzję określająca wysokość zobowiązania podatkowego w odniesieniu do aktywów lub przychodów pochodzących z innego państwa członkowskiego, jest nieproporcjonalne do celu $\mathrm{w}$ postaci zapewnienia poszanowania krajowych przepisów podatkowych ${ }^{33}$.

Z kolei w wyroku w sprawie Meilicke TSUE orzekł m.in., że uregulowanie krajowe w sposób bezwzględny uniemożliwiające osobom podlegającym nieograniczonemu obowiązkowi podatkowemu w zakresie podatku dochodowego od osób fizycznych w danym państwie UE, które dokonały inwestycji za granica, dostarczenia dowodów odpowiadających innym kryteriom niż przewidziane dla inwestycji krajowych przez przepisy pierwszego państwa, jest nie tylko sprzeczne z zasadą dobrej administracji, lecz przede wszystkim wykracza poza to, co jest konieczne do realizacji celu skuteczności kontroli podatkowych. Nie można bowiem, zdaniem Trybunału, wykluczyć a priori, że akcjonariusze sa w stanie przedłożyć odpowiednie dowody, na podstawie których organ podatkowy państwa członkowskiego opodatkowania mógłby w sposób jasny i precyzyjny skontrolować faktyczność i charakter poboru podatku dokonanego w innych państwach $\mathrm{UE}^{34}$.

${ }^{32}$ Zob. wyrok TS z 29 listopada 2011 r. w sprawie C-371/10 - National Grid Indus BV v. Inspecteur van de Belastingdienst Rijnmond/kantoor Rotterdam, ECR [2011], s. I-12273, pkt 85.

${ }^{33}$ Zob. wyrok TS z 11 czerwca 2009 r. w sprawach połączonych C-155/08 i C-157/08 X (C-155/08) - E.H.A. Passenheim-van Schoot (C-157/08) v. Staatssecretaris van Financiën, ECR [2009], s. I-5093, pkt 59-60.

${ }^{34}$ Zob. wyrok TS z 30 czerwca 2011 r. w sprawie C-262/09 - Wienand Meilicke, Heidi Christa Weyde, Marina Stöffler v. Finanzamt Bonn-Innenstadt, ECR [2011], s. I-5669, pkt 43-44. 
Organy państwa członkowskiego nie mogą ponadto w sposób ogólny domniemywać, że podmioty i jednostki mające siedzibę w innym państwie UE prowadzą działalność przestępczą. Fakt wyłączenia w sposób ogólny z możliwości korzystania ze zwolnienia podatkowego takich podmiotów jest nieproporcjonalny, gdyż wykracza poza to, co niezbędne do zwalczania przestępczości - istnieje bowiem szereg środków służących kontroli działalności i księgowości spółek z innych państw członkowskich ${ }^{35}$.

Z kolei w wyroku w sprawie Hein Persche Trybunał za nieproporcjonalne uznał wyłączenie możliwości odliczenia od podatku dochodowego darowizn dokonanych na rzecz organizacji mających siedzibę i uznanych za organizacje pożytku publicznego w państwie członkowskim innym niż państwo członkowskie darczyńcy, argumentując, że nie może być to usprawiedliwione trudnościami ze strony państwa członkowskiego darczyńcy w zbadaniu, czy takie organizacje skutecznie spełniają cele statutowe w rozumieniu przepisów krajowych, oraz koniecznością kontroli rzeczywistego zarządu tymi organizacjami ${ }^{36}$.

Warto również przywołać rozstrzygnięcie Trybunału w sprawie Komisja v. Portugalia, z którego wynika, że nakładanie na podatników niebędących rezydentami danego państwa członkowskiego obowiązku ustanowienia przedstawiciela podatkowego w tym państwie, w sytuacji gdy osiagają oni przychody, z którymi łączy się wymóg złożenia deklaracji podatkowej, stanowi ograniczenie swobody przepływu kapitału. Trybunał zgodził się ze stanowiskiem prezentowanym przez Komisję Europejska, że obowiąek wyznaczenia przedstawiciela podatkowego przez nierezydentów uzyskujących w innym państwie członkowskim przychody, z którymi związany jest wymóg złożenia deklaracji podatkowej, jest sprzeczny ze swobodnym przepływem osób i kapitału, ponieważ jest on jednocześnie „dyskryminujący i nieproporcjonalny do celu zmierzającego do zapewnienia skuteczności kontroli podatkowych i zwalczania unikania opodatkowania". Takie utrudnienie swobodnego wyboru dokonywanego przez podatnika prowadziłoby do nakładania dodatkowego ciężaru podatkowego na nierezydentów, który byłby nadmierny z punktu widzenia zamierzonego celu i mógłby zostać osiagnięty przez wykorzystanie mechanizmów dostępnych na podstawie unijnych regulacji w zakresie współpracy organów podatkowych ${ }^{37}$.

Dynamika i wielokierunkowość procesów integracyjnych w Unii Europejskiej powoduja, że znaczenie zasady proporcjonalności $\mathrm{w}$ sferze podatków bezpośrednich będzie wzrastać. Wpływ na to maja przede wszystkim obecna struktura i wzajemne relacje systemów podatkowych państw członkowskich, które mimo braku formalnej kompleksowej harmonizacji na poziomie unijnym, z wyjątkiem podatku VAT, mogą korzystać z pozostawionej im autonomii w zgodzie ze swobodami rynku wewnętrznego. To rodzi szczególną

${ }^{35}$ Zob. wyrok TS z 6 października 2009 r. w sprawie C-153/08 - Komisja Wspólnot Europejskich v. Królestwo Hiszpanii, ECR [2009], s. I-9735, pkt 39.

${ }^{36}$ Zob. wyrok TS z 27 stycznia 2009 r. w sprawie C-318/07 - Hein Persche v. Finanzamt Lüdenscheid, ECR [2009], s. I-359, pkt 51-52.

${ }^{37}$ Zob. wyrok TS z 5 maja 2011 r. w sprawie C-267/09 - Komisja Europejska v. Republika Portugalska, ECR [2011], s. I-3197, pkt 14 i 61. 
potrzebę oceny środków prawnych i faktycznych stosowanych przez państwa UE w kwestii podatków bezpośrednich, czy dla osiagnięcia określonych celów wewnętrznych państwa członkowskie, ograniczając zakres gwarantowanych swobód rynku wewnętrznego, czynią to w sposób możliwie najmniej obciążający podatników, a szczególnie podatników niebędących rezydentami podatkowymi danego państwa UE.

\section{UWAGI KOŃCOWE}

Podatki bezpośrednie nie zostały jak dotąd poddane kompleksowej harmonizacji w Unii Europejskiej. Państwa członkowskie dysponują nadal istotna autonomią w tej części krajowych systemów podatkowych. Z ugruntowanego orzecznictwa Trybunału wynika jednak, że państwa UE powinny korzystać z posiadanej autonomii podatkowej w sposób, który gwarantuje poszanowanie prawa unijnego, a w szczególności swobód rynku wewnętrznego. Przepisy Traktatu o funkcjonowaniu Unii Europejskiej przewidują szczególne okoliczności, które mogą uzasadniać ograniczenie przez państwa UE gwarantowanych swobód przepływu - np. bezpieczeństwo publiczne czy ochrona środowiska. Ponadto TSUE swoim orzecznictwem wypracował szereg tzw. podatkowych względów interesu ogólnego, jak spójność systemu podatkowego, zrównoważony podział kompetencji podatkowych czy zapobieganie uchylaniu się od opodatkowania, na które mogą powoływać się państwa członkowskie, uzasadniając ograniczenia swobód rynku wewnętrznego. Aby zapobiec nadużywaniu tych uprawnień przez państwa UE, Trybunał konsekwentnie wykorzystuje zasadę proporcjonalności do oceny zasadności zastosowanych środków krajowych. Proporcjonalność, w znaczeniu promowanym przez Trybunał, oznacza adekwatność (odpowiedniość) użytych środków do założonych celów przy zastosowaniu możliwie najmniej dolegliwych dla podatników rozwiązań legislacyjnych.

Obserwowany wzrost intensywności stosowania zasady proporcjonalności w orzecznictwie Trybunału w sprawach zakresu opodatkowania bezpośredniego jest konsekwencją zarówno fragmentarycznej harmonizacji materialnego prawa podatkowego państw członkowskich w tej sferze, jak również braku skutecznych mechanizmów transgranicznych kontroli podatkowych i wymiany informacji między organami podatkowymi państw członkowskich. To powoduje, że odmienne (mniej korzystne bądź dyskryminujace) traktowanie na gruncie podatków bezpośrednich podatników będących rezydentami innych państw UE poszczególne państwa członkowskie próbują uzasadniać szczególnymi podatkowymi względami interesu ogólnego, mającymi gwarantować m.in. skuteczność krajowych kontroli podatkowych, przeciwdziałać uchylaniu się od opodatkowania czy zapewnić spójność krajowych systemów podatkowych. Wydaje się, że podatnicy znajdujaccy się w sytuacjach transgranicznych w EU dostrzegli możliwości płynące z powoływania się w sporach z organami podatkowymi państw członkowskich na wymóg proporcjonalności stosowa- 
nych krajowych konstrukcji prawnych podatków bezpośrednich w odniesieniu do uzasadnionych nawet ograniczeń swobód rynku wewnętrznego. Trybunał Sprawiedliwości UE, rozstrzygając tego typu sprawy, nie może jednak pomijać argumentów państw członkowskich wskazujących na stopniową faktyczna utratę suwerenności podatkowej w związku z wieloma przejawami ponadgranicznej aktywności podatników w Unii Europejskiej. To swoiste „ważenie” powyższych zasad, wartości i uzasadnień staje się coraz trudniejszym zadaniem dla TSUE.

dr Rafat Lipniewicz

Uniwersytet Wroctawski

rafal.lipniewicz@uwr.edu.pl

\section{THE PRINCIPLE OF PROPORTIONALITY AND TAX LIMITATIONS \\ OF EU FUNDAMENTAL FREEDOMS}

\section{Sum mary}

European integration involves many socio-economic areas, including tax systems of EU Member States. Indirect taxes have been harmonised, while direct taxation remains a domain of the member states. The autonomy in the area of direct taxation does not, however, mean full sovereignty. Member States have to take into account the fundamental freedoms of the EU internal market, the restricting of which should be evaluated in the light of the principle of proportionality. 
